\title{
The Influence of Endogenous Factors on Entrepreneurial Success Among Youths in Masvingo Urban, Zimbabwe
}

\author{
Chrispen Maireva ${ }^{*}$ and Nzwirashe Rejoyce Magomana \\ Robert Mugabe School of Education and Culture, Great Zimbabwe University \\ "Corresponding Mail: cmaireva@gzu.ac.zw
}

\begin{abstract}
This study sought to establish the influence of endogenous factors on entrepreneurial success among youths. The study adopted a quantitative correlational research approach. The population of the study comprised of 420 youth entrepreneurs in Masvingo Urban. A sample of 201 respondents was drawn from the population using a random sampling technique. The data was collected using a structured questionnaire and analysed using descriptive statistics and multiple regression analysis. The study found that the level of education, management skills, previous entrepreneurial experience, cultural background and the personal characteristics, attributes, skills, and attitudes of the youth entrepreneurs influenced their entrepreneurial success. The level of education, entrepreneurial training and the requisite technical skills also helped the youth entrepreneurs to grow their businesses. The cultural background was found to have an influence on the youth entrepreneurial success. The study recommended that availability of funds, coupled with training and enhancement of entrepreneurial skills by government agencies has the potential to improve the entrepreneurial activities.
\end{abstract}

Keywords: Youth entrepreneurship, entrepreneurial success, endogenous factors, youth unemployment, entrepreneurship culture.

\section{Introduction}

Most people in low-income countries are young, and a majority of them are poor (Woodruff, 2007). According to the United Nations, there are more than 1 billion young people between the ages of 16 and 34 globally defined as youth. Sub-Saharan Africa's population is growing rapidly, and its youths have limited income opportunities (Sambo, 2016). The International Labour Organisation (ILO) estimates that globally, $85 \%$ of young people live in developing countries. The ILO further anticipates that for the next 10 years, close to 100 million young people will enter the global workforce every year. Sub-Saharan Africa (SSA) remains the poorest region in the world, and estimates indicate that half of its population is below the age 18 .

In Zimbabwe, youth unemployment has become one of the most ubiquitous challenges in the economy because of the deteriorating socioeconomic and political landscape for the past two decades. Unofficial statistics point to an astounding 95\% overall unemployment rate (Worstzall, 2017). As a result, many young people have resorted to setting entrepreneurial businesses as a direct response to the unavailability of formal jobs. However, these young entrepreneurs face a variety of constraints that hinder the growth and development of their enterprises. The main factors that affect youth entrepreneurship in Zimbabwe were identified by Mubaiwa (2013) and Chimucheka (2012) as limited access to start-up investment capital, unavailability of work space and equipment, lack of marketing skills and market information, inadequate management and entrepreneurial skills, hostile regulatory environment, competition, bureaucracy and corruption, negative perceptions of youth entrepreneurs' product quality and efficacy as well as a difficult operating environment viz-a-viz high licensing fees, erratic utilities, political uncertainties and fluctuating exchange rates. The youths are also faced with other economic challenges emerging from the hyperinflationary period environment: a culture of senseless profiteering, poor service standards along the supply chain, rent seeking behavior and corruption in some registration offices, and competition with established monopolistic or deep pocketed local and foreign players. All this is in a business environment that regards youthfulness with suspicion, as many 
are still finding their feet into the world of business (Mubaiwa, 2013).

An entrepreneur is one who innovates, by making new things or by making things differently (Schumpeter, 2008). This study defines an entrepreneur as a person who sets up a business and takes on the financial risks with the main aim of making a profit. Herrington and Kew (2015) define entrepreneurship as any attempt at a new business or new venture creation, such as self-employment, a new business organization or the expansion of an existing business by an individual, a team of individuals or an established business. Lazear (2005) emphasizes that entrepreneurship requires the ability to combine resources simultaneously and efficiently. This study defines entrepreneurship as the process and activity of setting up a new business or venture for profit. The common thread in the above definitions, along many other definitions of entrepreneur and entrepreneurship, is the emphasis on the fact that entrepreneurship is the mind set and process to create, develop and grow a business enterprise through risk-taking, creativity, the integration of different resources, identification of market opportunities and/or innovation in a new or an existing organisation. Entrepreneurship is driven by the need to achieve certain rewards such as monetary profits, recognition, career growth, personal satisfaction and/or a change in lifestyle.

The urge to pursue entrepreneurship is normally influenced by a mixture of psychological, contextual and socio-cultural determinants or factors. Through several studies on the entrepreneurial phenomenon which have been carried out under the following themes: psychological (McClelland 1961), economic (Audretsch and Thurik, 2001) and sociological or institutional (Shapero and Sokol, 1982), it is apparent that the entrepreneur's activities occur within a wider environmental medium, which include the economic, political, legal, social, cultural and natural settings. Hence all these factors influence the entrepreneurial success.

Nieman (2006) defines endogenous factors that influence the entrepreneurial success as all the person-specific factors. These include the personal abilities and skills for performing the functions of the entrepreneur and the availability of resources and their effective use in the entrepreneurial business. Lighthelm and Cant (2000) argue that a deficiency of these internal attributes has been identified as one of the major causes of small business failure. Dockel and Ligthelm (2005) found that over $65 \%$ of all small business failures are caused by these endogenous factors. The endogenous factors include the demographics, previous entrepreneurial and work experience of the entrepreneur, personal characteristics, abilities, skills and capabilities of the entrepreneur.

One critical entrepreneurial success factor is culture (Davidsson, Delmar, \& Wiklund, 2006). According to Davidsson (1995), culture may influence entrepreneurship through two main mechanisms. Firstly, a supportive culture would lead to social legitimation, making the entrepreneurial career more valued and socially recognized in that culture, thus creating a favorable institutional environment. Therefore, more people will try to start their ventures, irrespective of their personal beliefs and attitudes. Secondly, a culture sharing more proentrepreneurial values and patterns of thinking would lead to more individuals showing psychological traits and attitudes consistent with entrepreneurship (Krueger, 2003), thus, channeling more people, particularly the youth, to become entrepreneurs (Mueller \& Thomas, 2001).

An entrepreneurial mindset is important when discussing the entrepreneurial success. According to Bjorvatn (2015), the fact that a person is running a business, and hence being an entrepreneur, is not evidence of an entrepreneurial mindset. In broad terms, entrepreneurship literature divides entrepreneurs into two main categories: necessitydriven entrepreneurs and opportunity-driven entrepreneurs (Lazear, 2005; del Mel, McKenzie \& Woodruff, 2012; Woodruff, 2007). Necessity-driven entrepreneurs are those that are forced by circumstance into setting up a business because that is the only way they can earn a living. Their enterprises are of a survivalist nature. On the other hand, an opportunity-driven entrepreneur is one who is motivated by business opportunities available in the market. A person who sets up a business for the lack of alternative options (a necessity-driven entrepreneur) cannot be expected to have the same drive for growth as a person who chooses to set up a business with other income generating options available (an opportunity-driven entrepreneur) (Bjorvatn, 2015). Herrington and Kew (2015) show that necessity-driven entrepreneurship is more common in developing countries than in developed countries. Additionally, they also report that opportunity-driven businesses have a greater 
impact on employment than necessity-driven businesses.

According to de Mel, McKenzie and Woodruff (2010), access to finance is not the primary constraint to growth for the majority of the small business entrepreneurs. They conclude that microenterprise owners lack in cognitive ability, personality and ambition. Echoing the emphasis on knowledge and mindset as binding constraints to microenterprise development, Olomi (2007) states that one of the most debilitating constraints in entrepreneurial success is limited awareness and capacity of existing and potential business operators, in terms of exposure, values, attitudes, knowledge and skills. Berge, et al., (2014) show that the willingness to compete (competitiveness) is a key entrepreneurial trait.

According to Herrington, Kew, and Kew (2009), the Global Entrepreneurship Monitor (GEM) surveys carried out over the years have conclusively shown that the low level of early-stage entrepreneurial activity in SSA is influenced by a low level of overall education, especially in maths and science as well as in social and cultural aspects, which does not encourage entrepreneurship as a career path of choice. In a study by Turton and Herrington (2012) in South Africa, it was found that a low level of overall education and training is still the biggest challenge facing young entrepreneurs. As such, a critical performance area must be to improve the overall level of education and training whilst promoting the notion of entrepreneurship (Nicolaides, 2011). Furthermore, literature on entrepreneurship emphasises that people with a higher level of education have a higher propensity to be self-employed (Preisendorfer, Bitz \& Bezuidenhout, 2012). Therefore, educational background is an important factor to consider for effective entrepreneurship to be realized.

Steenekamp, van der Merwe and Athayde (2011) stress that the passing on of innovative knowledge and skills should be built-in into the basic education goals, if school leavers are to be expected to play a meaningful role in economic activity. Included in the entrepreneurial capacity factors are personality traits, learning, experiences, social factors and culture. These factors are found to be among the main issues influencing the success of entrepreneurship in youths, women and other disadvantaged groups (Dionco-Adetayo, 2006).
According to Preisendorfer, et al., (2012), the need to enhance the low level of formal education for the young people is a widely accepted goal of the education system in most African countries. They argue that improved formal education among the youth will address, among other socio-economic problems, the impact that colonial education had on its people. Colonial education not only damaged people's confidence and self-esteem but it also deliberately inculcated a kind of passivity and learning helplessness (Western Cape Youth Commission, 2008). In another study in South Africa, Preisendorfer et al. (2012, p.15) argued that, "... the main problems of black South Africans are a low level of self-confidence and risk propensity, a culture of dependency and collectivism, missing strong ties to the "business world." They go further to postulate that the most serious obstacle to an increased participation of youth in entrepreneurial activities is the skills component.

According to Herrington and Kew (2015), entrepreneurs require the kind of education which inculcates basic literacy and numeracy skills. They also argue that formal businesses require specific training in skills such as how to keep records, budgeting, managing cash flow, maximizing trade credit and writing a business plans. This is in line with the recommendations of the GEM report (2003) which discovered that the problem in the education and training system may well account for the low levels of the entrepreneurial activity.

Some school-leavers do not have sufficient literacy, numeracy and livelihood skills to be able to participate actively in the economy as was found in studies in South Africa (Herrington \& Pew, 2015; Preisendorfer, et al., 2012). These studies further found that some of those that attempted to engage in business activities lacked managerial, technical and marketing skills and were therefore at a disadvantage position in a competitive, challenging and changing business environment.

Young people that cannot find a way to sustain their livelihood are at a particular risk of becoming involved in anti-social behaviors and therefore it is imperative to find avenues for them to participate in the economy in a meaningful way. Furthermore, training after school is more strongly linked to entrepreneurial behavior for both genders, but this was particularly the case for young women. Thus, there is also a need for life skills training in the education curriculum for young people (Preisendorfer et al., 2012; Nicolaides (2011). 
According to Turton and Herrington (2012), there is a positive correlation between opportunity-driven entrepreneurship and levels of education. Education is inextricably linked to entrepreneurial intentions and growth as it influences entrepreneurs' confidence in whether they have the skills and knowledge to start a business. GEM reports have suggested that there is an association between educational levels and success in entrepreneurial ventures. Therefore, a country's skills level is certainly an important contributing factor to the country's entrepreneurial capacity (Herrington and Kew, 2015). Entrepreneurial experience is also another important factor in entrepreneurial skills development. The greater the entrepreneur's business experience, the greater the chances of success. The GEM survey indicates that ventures started by people with entrepreneurial experience are more likely to survive than those that are initiated by people lacking business experience (Driver, Wood, Herrington, \& Segal, 2001). One of the critical success factors concerns mind-sets; more specifically, the cultural norms and attitudes in a community regarding business failure. In most highimpact entrepreneurship communities, business failure is often seen as positive and a way to learn invaluable business lessons.

Entrepreneurial experience and/or education help youth develop new skills that can be applied to various challenges in life. Skills such as opportunity recognition, innovation, critical thinking, resilience, decision-making, teamwork and leadership benefit the youth who intend to become entrepreneurs (Chiloane-Tsoka \& Botha, 2015). There is evidence that practical entrepreneurship training may better prepare school leavers for the transition from school to the labour market and enable them to identify business opportunities and improve their chances of success in business and self-employment ventures. Entrepreneurship education can enhance an individual's level of self-efficacy and increase students' interest in entrepreneurship as a viable career choice (Herrington and Kew, 2015).

The 2015 GEM Youth Report showed a positive link between training in starting a business and entrepreneurial behavior. Entrepreneurs across all age categories were 1.5 times more likely to have received some form of business training, compared to the non-entrepreneurs. Young people who received business training at school were 1.2 times more likely to be entrepreneurs than those who had not received the training. For youth who pursued post-school business training, males were 1.5 times and females 1.8 times more likely to become entrepreneurs. This confirms the findings by Nicolaides (2011) who found that females who receive business training were more likely to be successful. Thus, mentorship, guidance and small business training support are essential components of the entrepreneurial development, and ultimately entrepreneurial success among the youth. Therefore, business and entrepreneurial training are essentials for the success of young entrepreneurs.

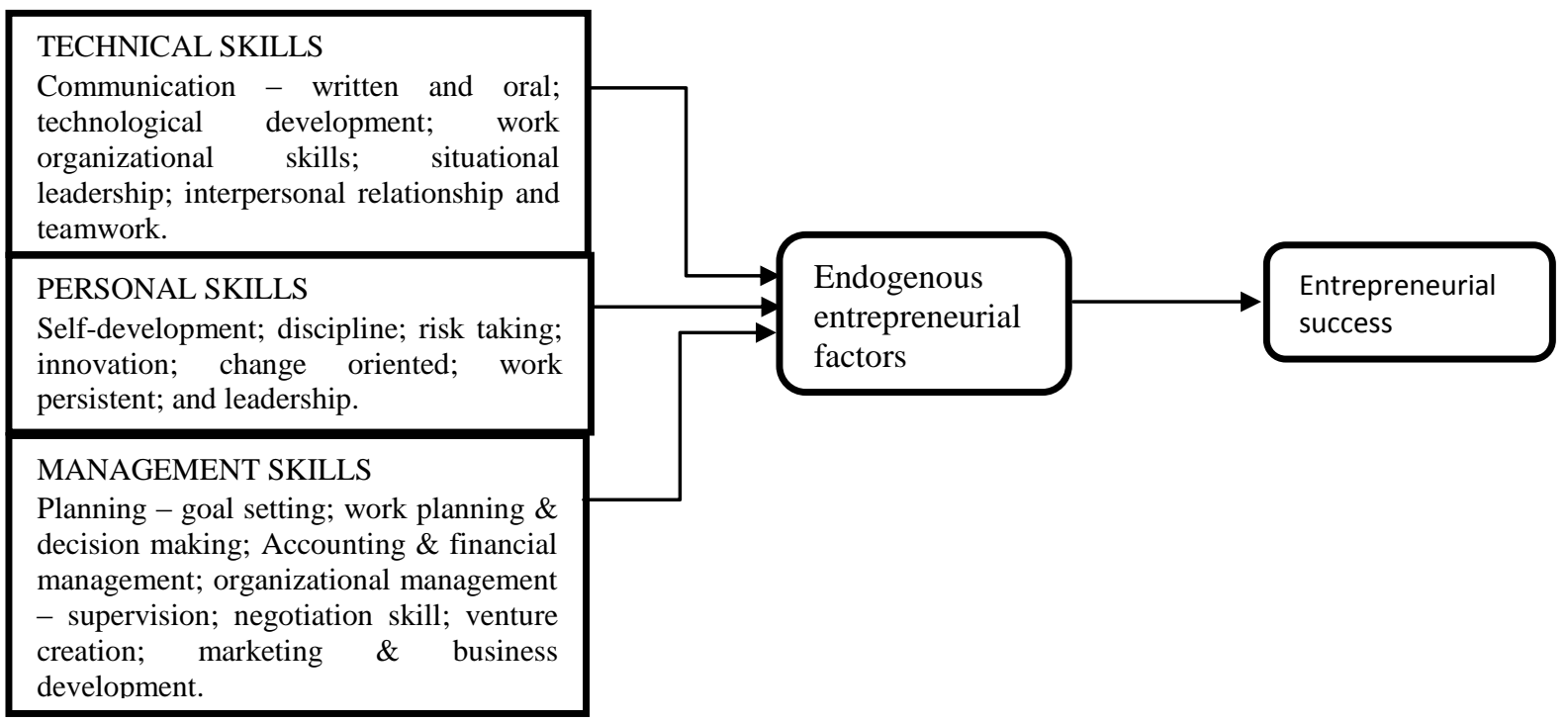

Figure 1: Indigenous Factors Influencing Entrepreneurial Success among Youths

Given that starting a business is a risky process that entrepreneurial development and success. For often involves cycles of failure (Sambo, 2016), a harsh attitude to failure would be a limiting factor in example, Herrington and Kew (2015) propose that as part of the youth entrepreneurial development 
process, universities, colleges and technoinnovation parks should not only focus on traditional training and research. Instead, they should adopt a more proactive approach in the provision of training and research which young entrepreneurs can use to enhance the growth and development of their enterprises.

Successful small businesses positively correlate with the entrepreneur's level of entrepreneurial acumen. Furthermore, SMME support programmes tend to focus on businesses with growth potential rather than survivalist businesses with limited potential. Successful businesses show a positive correlation between business management skills and entrepreneurial behaviour (Dockel \& Ligthelm, 2005). Figure 1 (p. 182) depicts the conceptual framework developed by the authors with adaptations from the critical entrepreneurial skills propounded by Kuratko and Hodges (2001).

Kuratko and Hodgetts (2001) identified three dimensions of critical entrepreneurial skills namely technical, personal and management skills, which they considered important for the entrepreneurial success. They argue that to be successful, an entrepreneur needs to have certain skills. Technical skills cover aspects such as communication - both written and oral, environmental change, technological development, work organisational skills, situational leadership, interpersonal relationships and teamwork skills. Thus, the entrepreneur requires technical skills to be successful in the enterprise. They further postulate that business management skills encompass the ability of the entrepreneurs to set organisational goals, plan their work and make informed decision.

This study was guided by the following research questions:

1. What is the influence of the entrepreneurs' level education on the entrepreneurial success of youth enterprises?

2. Does the cultural background of the entrepreneur determine their entrepreneurial success?

3. What is the effect of the personal skills on the entrepreneurial success of youth enterprises?

\section{Methodology}

This study employed a quantitative correctional research design (Salkind, 2012). A correlational research study describes the casual relationship between two or more variables (Sekaran \& Bougie, 2016). Thus, the correlational research was found to be the most appropriate in this study as it sought to establish if a relationship existed between endogenous factors and entrepreneurial success among the youths.

\section{Population and Sampling}

The population of the study comprised of 420 youth entrepreneurs aged between 18 years and 35 years old in Masvingo Urban. These youth were identified from the database of youth entrepreneurs registered with a youth entrepreneurial organisation with operations in the area under study. From this population, a sample of 201 respondents was drawn using the Krejcie and Morgan (1970) formula. The sample was drawn using a probabilistic sampling technique called random sampling. The random sampling technique was chosen as it was found to be the most suitable method in this study, given that it was a quantitative correlational study (Sekaran \& Bougie, 2016).

\section{Instrumentation}

A self-administered questionnaire was employed to collect data from the respondents. The biggest advantage of the questionnaire was its ability to save time and to allow the respondents to complete them without the assistance of the researchers. The questionnaire was a structured five-point Likertscale, close-ended type. The questionnaire was administered on a randomly selected sample of 201 entrepreneurial youths in Masvingo Urban in the age range of $18-35$ years.

\section{Statistical Treatment of Data}

On data analysis, the researchers first checked quantitative data collected for completeness. The data were then coded and captured into a computer program for analysis. The data was analysed with the aid of the Statistical Package for Social Sciences (SPSS) version 22. Data was analysed using Descriptive Statistics and Pearson correlational coefficient and the Analysis of Variance (ANOVA). The $p$-value was used to ascertain whether there was a relationship between the two variables. The researchers created four dummy variables namely: Entrepreneurial success (entre-success) which is the dependent variable of the study. On the other hand, the independent variables of the study were identified as level of education, experience and management skills (edu-man-exp); cultural background (culture), personal attitudes, skills and attributes (owner-attitude). The reliability of the 
four dummy variables was checked (Cronbach, 1951). The alphas for the four variables were 0.63; $0.73 ; 0.84$; and 0.6 respectively. An acceptable Cronbach's Alpha, according to Cooper and Schindler (2014), should be a minimum of 0.6.

\section{Ethical Considerations}

In carrying out this study, the researchers ensured matters of confidentiality anonymity of the respondents by ascribing a number to each respondent. It was only the researchers who had a record of the respondent and their corresponding number. Each respondent had to voluntarily participate in the study. In order to do so, the respondents had to confirm their willingness to participate by signing an informed consent form prior to taking part in the survey and completing the questionnaire. Thus, all respondents who participated in this study did so willingly.

\section{Results and Discussion}

The main purpose of carrying out this study was to determine the influence of the critical endogenous factors on the entrepreneurial success among youths. The analysis was done through research questions.

Research question 1: What is the influence of the entrepreneur's level of education on the success of youth enterprises?

From the survey, $80 \%$ of the respondents agreed or strongly agreed that the level of education a youth had a significant influence on whether they would succeed in their entrepreneurial endeavor or not. It was found that $20 \%$ of the respondents disagreed or strongly disagreed with the assertion. Thus, the study respondents indicated that the level of education was important as it allowed the entrepreneurs the opportunity of acquiring the relevant skills, such as management skills which can be learnt in school, college or university. These skills are necessary and critical for a successful running of the business. The study's findings concur with Kuratko and Hodgetts (2001) who identified management skills as some of the critical factors that may affect entrepreneurial success among the youths.

The study also found that $85 \%$ of the respondents strongly agree or agreed with the assertion that entrepreneurial experience was an important indicator of entrepreneurial success. It was also found that in addition to personal skills, previous work experience in the same or similar line of business as well as entrepreneurial experience played a very important role in the entrepreneurial success of the youth enterprises. Hence, those entrepreneurs who had some sort of experience in running an enterprise were likely to succeed, given that they have the benefit of the learning curve. This is because once someone has the experience in running an enterprise, they tend to learn from their previous mistakes.

Another critical factor that is closely related to entrepreneurial experience is management skills. It was found that $80 \%$ of the respondents agreed or strongly agreed that possession of management skills had an important influence on the entrepreneurial success among youths. Those youths who had previous experience were able to perform several critical management functions in their businesses, which had a direct bearing, and positive effect on their ability to run successful enterprises. These activities included goal setting, work planning and organisation, decision making, financial management, bookkeeping and accounting, general organisational management, supervision, negotiation skills, venture creation, marketing management and business development. All these skills and competences are important in ensuring that the business of the entrepreneur can succeed. These findings are depicted in the figure 2.

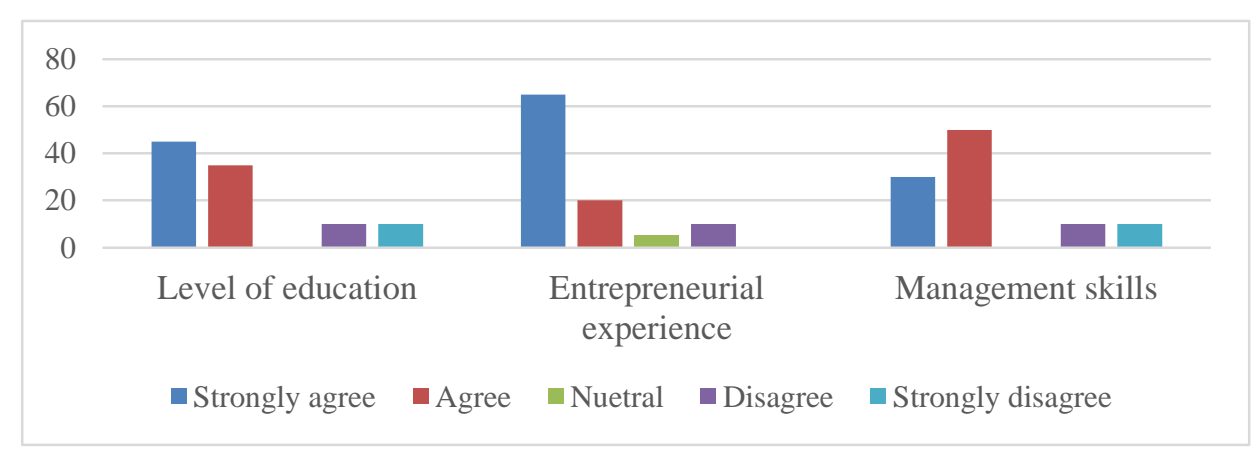

Figure 2: The influencing of level of education on entrepreneurial success among youth

184 East African Journal of Education and Social Sciences (EAJESS) 2(2)179-189 
Research question 2: Does the cultural background of the entrepreneur determine their entrepreneurial success?

The respondents were asked a series of questions to find out whether the cultural background of the entrepreneur determined the entrepreneurial success. Cultural background was also found to play a critical role in the success of enterprises. This was alluded to by $75 \%$ of the respondents who agreed or strongly agreed with the assertion that culture played a significant role in an individual taking up entrepreneurship as a career choice, making a success out of it. It was found that $20 \%$ disagreed or strongly disagreed with the statements that culture was an important predictor of entrepreneurial success.
The cultural norms, values and attitudes were also identified as one of the impediments to the entrepreneurial success in a study by Nicolaides (2011) and Preisendorfer, et al., (2012). Herrington and Kew (2015) who conducted a study in South found that generally, the black population did not have a culture of running successful businesses when compared to whites and people of Asian origin (Indian, Chinese, Pakistanis) and people of mixed race. Thus, as alluded to by King'ori (2012), most of the education systems in SSA are aimed to produce graduates who are ready to take up employment, rather than the running of their own enterprises. Therefore, most of them indicated that they had been schooled to be employed and look for jobs instead of running the business themselves. These findings are depicted in figure 3.

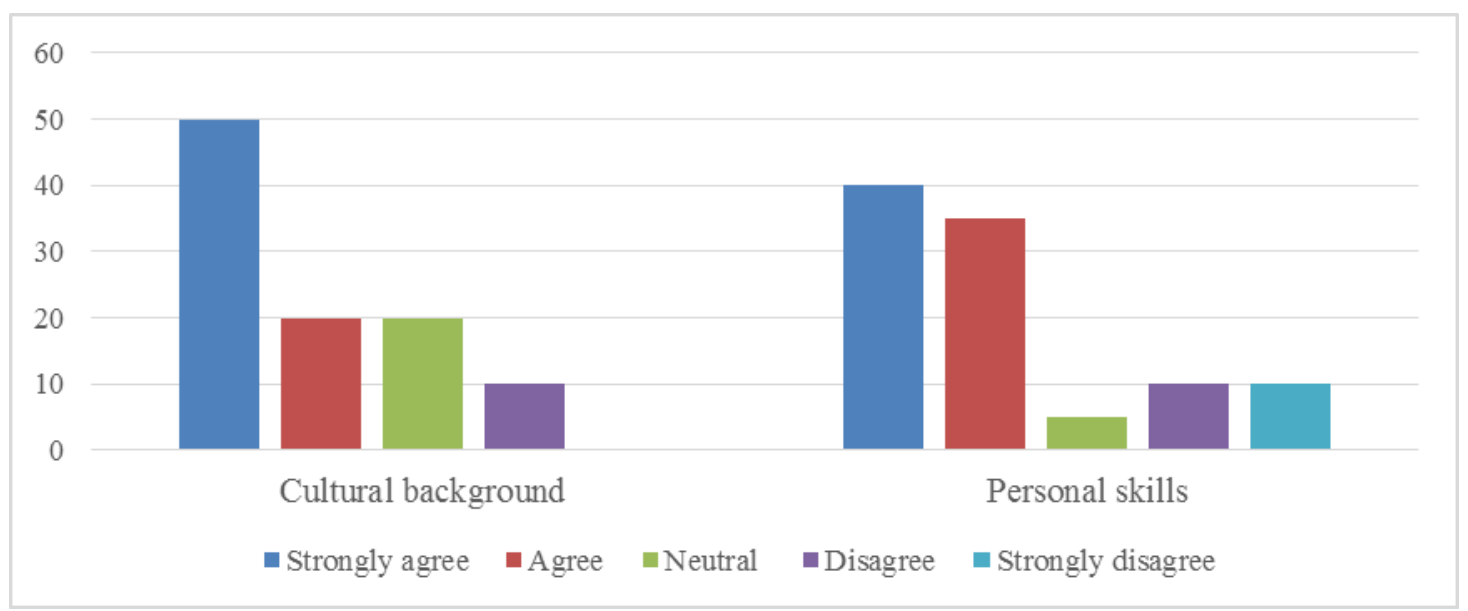

Figure 3: Influence of Cultural Background and Personal Skills On Entrepreneurial Success

Therefore, attitude of the entrepreneur are crucial for entrepreneurial success. The finding is harmony with Kuratko and Hodgets (2001) who argued that personal attributes, attitudes, and characteristic were found to have influence on the entrepreneurial success of the youths.

Research 3: What is the effect of the personal skills on the entrepreneurial success of youth enterprises?

In terms of personal skills, majority agreed that persons with the requisite personal skills had the capacity to successfully run their enterprises. The pertinent personal skills that were termed the entrepreneurial skills by Kuratko and Hodgetts (2001) include self-development, self-efficacy, selfesteem, discipline and risk-taking as depicted in figure 3. Therefore, attitudes of the entrepreneur were found to be crucial for entrepreneurial success among the youth. The finding is in harmony with
Kuratko and Hodgets (2001) who argued that personal attributes, attitudes, and characteristic were found to have influence on the entrepreneurial success of the youths.

\section{Correlation Analysis}

It was found that the correlation between entrepreneurial success, which was a dependent variable of the study, and the three independent variables namely level of education, cultural background and the entrepreneur's personal skills, attitudes, characteristics and attributes was positive.

There was found to be a positive correlation between entrepreneurial success and the level of education, experience, and management skills of 0.781 . This implies that there was a high correlation which indicates a strong positive relationship between the two variables. This means that young business owners were likely to succeed in business 
in cases where they have achieved some level of education or acquired sufficient work and entrepreneurial experiences.

There was also found to be a strong positive correlation between entrepreneurial success and the personal characteristics, attitudes, attributes, and skills of the business owners. The $r$ value for the correlation was found to be 0.871 . The study also found a positive correlation between entrepreneurial success and the cultural background of the youth entrepreneurs. The $r$ value for the model was found to be 0.655 as shown in table 1 (p. 186).

In terms of the analysis of variance (ANOVA) in table 2 , there was found a statistically significant relationship between the dependent variable namely entrepreneurial success and the three independent variables namely level of education, experience and management skills, cultural background and personal attitudes, characteristics, skills and attributes. The $p$-value was 0.000 . This is below 0.05. According to Cohen, Manion and Morrision (2010) a p-value below 0.05 shows a statistically significant relationship between the dependent and independent variables.

In terms of the co-efficients of variation, it was found that there was a statistically significant relationship between the three variables as the $p$ value was less than 0.05 .

Table 1: Correlations

\begin{tabular}{|c|c|c|c|c|c|}
\hline & & entre_success & edu_man_exp & Culture & owner_attitude \\
\hline \multirow[t]{3}{*}{ Entre_success } & $\begin{array}{l}\text { Pearson } \\
\text { Correlation }\end{array}$ & 1 & $.781^{* *}$ & $.655^{* *}$ & $.871^{* *}$ \\
\hline & Sig. (2-tailed) & & .000 & .000 & .000 \\
\hline & $\mathrm{N}$ & 250 & 250 & 250 & 250 \\
\hline \multirow[t]{3}{*}{ Edu_man_exp } & $\begin{array}{l}\text { Pearson } \\
\text { Correlation }\end{array}$ & $.781^{* *}$ & 1 & $.399^{*}$ & $.844^{* *}$ \\
\hline & Sig. (2-tailed) & .000 & & .029 & .000 \\
\hline & $\mathrm{N}$ & 250 & 250 & 250 & 250 \\
\hline \multirow[t]{3}{*}{ Culture } & $\begin{array}{l}\text { Pearson } \\
\text { Correlation }\end{array}$ & $.655^{* *}$ & $.399^{*}$ & 1 & $.568^{* *}$ \\
\hline & Sig. (2-tailed) & .000 & .029 & & .001 \\
\hline & $\mathrm{N}$ & 250 & 250 & 250 & 250 \\
\hline \multirow[t]{3}{*}{ Owner_attitude } & $\begin{array}{l}\text { Pearson } \\
\text { Correlation }\end{array}$ & $.871^{* *}$ & $.844^{* *}$ & $.568^{* *}$ & 1 \\
\hline & Sig. (2-tailed) & .000 & .000 & .001 & \\
\hline & $\mathrm{N}$ & 250 & 250 & 250 & 250 \\
\hline
\end{tabular}

**. Correlation is significant at the 0.01 level (2-tailed).

*. Correlation is significant at the 0.05 level (2-tailed).

Table 2: Anova

\begin{tabular}{lllllll} 
Model & & Sum of Squares & Df & Mean Square & F & Sig. \\
\hline 1 & Regression & 1149.992 & 25 & 383.331 & 37.374 & $.000^{\mathrm{b}}$ \\
& & & & & \\
& & & & & \\
& Residual & 266.674 & 216 & & & \\
Total & 1416.667 & 242 & &
\end{tabular}

a. Dependent Variable: Entre_success

b. Predictors: (Constant), Owner_attitude, culture, edu_man_exp 
Table 3: Coefficients

\begin{tabular}{|c|c|c|c|c|c|c|}
\hline \multirow[b]{2}{*}{ Model } & & \multicolumn{2}{|c|}{ Unstandardized Coefficients } & \multicolumn{3}{|c|}{ Standardized } \\
\hline & & B & Std. Error & Beta & $\mathrm{T}$ & Sig. \\
\hline \multirow[t]{4}{*}{1} & (Constant) & 11.013 & 2.168 & & 5.081 & .000 \\
\hline & Edu_man_exp & .485 & .333 & .235 & 1.458 & .015 \\
\hline & Culture & .636 & .252 & .266 & 2.527 & .018 \\
\hline & Owner_attitude & .985 & .340 & .521 & 2.900 & .007 \\
\hline \multicolumn{7}{|c|}{ a. Dependent Variable: Entre_success } \\
\hline Model & $\mathrm{R}$ & R Square & Adjusted R S & yuare & Std. Error of the & nate \\
\hline 1 & $.901^{\mathrm{a}}$ & .812 & .790 & & 3.20261 & \\
\hline
\end{tabular}

a. Predictors: (Constant), Owner_attitude, culture, edu_man_exp

To determine how much of the entrepreneurial success is directly attributed to the three predictors (independent variables), the $r^{2}$ value was computed. Thus, the three variables can account for $7.9 \%$ of all the entrepreneurial success of the youth entrepreneurs in the Masvingo Urban. This information is depicted in the model summary in table 3 ..

\section{Conclusions and Recommendations}

This part presents the conclusions of the study and then comes up with recommendations.

\section{Conclusions}

Based on the findings of the study, it has been concluded that level of education, management skills, previous entrepreneurial experience, work experience, the cultural background and the personal characteristics, attributes and attitudes of the youth are critical factors in influencing the entrepreneurial success among the youth in Masvingo Urban. A positive correlation was found to exist between the entrepreneurial success and the level of education, management skills and previous entrepreneurial and work experience.

\section{Recommendations}

It is imperative and incumbent upon the government of Zimbabwe to understand the entrepreneurial needs of young Zimbabweans and other factors inhibiting their growth. High impact and quality entrepreneurial education and training is necessary in stimulating the entrepreneurial activity among the youth instead of a purely academic education which does not provide proactive searching of business opportunities and taking of risks.

\section{Reference}

Audretsch, D. B. \& Thurik, R. (2001). What's new about the new economy? Sources of growth in the managed and entrepreneurial economies. Industrial and Corporate Change.

Berge, L. I, O., Bjorvatn, K., \& Tungodden, B. (2014). Human and Financial Capital for Microenterprise Development: Evidence from a Field and Lab Experiment. Management Science.

Chiloane-Tsoka, G. E., \& Botha, A. (2015). Factors influencing urban youth entrepreneurship development in subSaharan Africa. Problems and Perspectives in Management, 13(4-1), 230-239.

Chimucheka, T. (2012). Impediments to youth entrepreneurship in rural areas of Zimbabwe. African Journal of Business Management, 6 (38), pp. 10389-10395.

Cooper, D. R. \& Schindler, P. S. (2014). Business research methods, Twelfth Edition. New York: McGraw-Hill Companies, Inc.

Cronbach, L. J. (1951). Coefficient alpha and the internal structure of tests. Psychometrika, 16 (3), 297-334.

Davidsson, P. (1995). Culture, structure \& regional levels of entrepreneurship. Entrepreneurship and Regional Development.

Davidsson, P. Delmar, F. \& Wiklund, J. (2006), Entrepreneurship and the Growth of Firms. Cheltenham and Northampton, MA: Edward Elgar. 
de Mel, S., McKenzie, D., \& Woodruff, C. (2012). One-time transfers of cash or capital have long-lasting effects on microenterprises in Sri Lanka. Science, 24 (335): 962 - 966.

de Mel, S., McKenzie, D., \& Woodruff, C. (2010). Who are the microenterprise owners? Evidence from Sri Lanka on Tokman versus De Soto, Chapter 2 in Josh Lerner and Antoinette Schoar (eds.) International differences in entrepreneurship, University of Chicago Press.

Dionco-Adetayo, E. A. (2006). Factors Influencing Attitude of Youth towards Entrepreneurship, International Journal of Adolescence and Youth, 13, pp. 127 145.

Dockel, J. A., \& Lighthelm, A. A. (2002). Factors that contribute to small business survival. Southern Africa Business Review, 6(2): 1-7.

Dockel, J. A., \& Lighthelm, A. A. (2005). Factors responsible for the growth of small businesses. South African Journal of Economic and Management Sciences, 8(1): 54-62.

Driver, A., Wood, E., Herrington, M. \& Segal, N. (2001). Global Entrepreneurship Monitor: 2001 South African Executive Report. Graduate school of Business, Cape Town.

Global Entrepreneurship Monitor Report, (2014). [Online]. Available: http://www.gemc ons ortium.org/docs/download [Accessed: January 27, 2019].

Herrington, M \& Kew, $P$ (2015). Global Entrepreneurship Monitor: South Africa Report 2015/16. Cape Town: UCT Press.

Herrington, M., Kew, J. \& Kew, P. (2009). Global Entrepreneurship Monitor, South African Report. [Online]. Available: http://www.gbs.nct.ac.za/gbswebb/userfile s/gemsouthafrica2000pdf [Accessed: April 12, 2019].

King'ori, E. N. (2012). Factors Influencing Sustainability of Youth Group Enterprises: The case of Small and Medium Enterprises in Nyeri Town municipality. University of Nairobi, Nairobi.
Bjorvatn, K. (2015). Youth, entrepreneurship and development. Rapport 2015:04. EBA: Stockholm.

Krueger, N.F. (2003). The cognitive psychology of entrepreneurship. In Handbook of entrepreneurship research: An interdisciplinary survey and introduction, London.

Krejcie, R. \& Morgan, D. (1970). Determining sample size for research activities. Educational and Psychological Measurement, 30, 607610.

Kuratko, D. F. \& Hodgetts, R. M. (2001). Entrepreneurship: A Contemporary Approach. Mason, $\mathrm{OH}$ : South-Western Thomson Learning.

Lazear, E. P. (2005). Entrepreneurship. Journal of Labor Economics, 2005, vol. 23, no. 4: 649-680.

Ligthelm, A. A \& Cant, M. C. (2002). Business success factors for SMEs in the Gauteng Province. Pretoria: UNISA Publications.

McKenzie, D \& Woodruff, C. (2012). What are we learning from business training and entrepreneurship evaluations around the developing world?" World Bank Research Observer, 29(1): $48-82$

McClelland, D. C. (1961). The achieving society. Princeton, NJ: Van Nostrand.

Mueller, S. L., \& Thomas, A. S. (2001). Culture and entrepreneurial potential: A nine country study of locus of control and innovativeness. Journal of Business Venturing Volume 16, Issue 1, January 2001, Pages 51-75.

Mubaiwa, K. (2013). The Unique Challenges of Youth Entrepreneurs in Zimbabwe: Is Access to Credit Enough? Presented at the Business and Entrepreneurship Conference Makerere University business school, Kampala, Uganda 24 May 2013.

Nicolaides, A. (2011). Entrepreneurship - the role of Higher Education in South Africa. Education Research, 2(4), 1043-1050.

Nieman, G., (2001). Training entrepreneurs and small business enterprises in South Africa: a situational analysis. MCB University press. 
Olomi, D. (2007). Unleashing entrepreneurial potentials of the poor in Tanzania: prospects, challenges, and way forward. mimeo, University of Dar es Salaam Entrepreneurship Centre, Dar es Salaam.

Preisendorfer, P., Bitz, A., \& Bezuidenhout, F. J. (2012). In Search of Black Entrepreneurship: Why Is There a Lack of Entrepreneurial Activity among the Black Population in South Africa? Journal of Developmental Entrepreneurship, 17(1), 1-18.

Salkind, N. J. (2012). Exploring Research, $8^{\text {th }}$ Edition. University of Kansas, USA: Pearson.

Sambo, W. (2016). Factors affecting youth entrepreneurship development within Kibera, Kenya: the perspective ofentrepreneurship education. Problems and Perspectives in Management, Volume 14, Issue 2, 2016, pp 331 - 338.

Schumpeter, J. A., 1934 (2008). The Theory of Economic Development: An Inquiry into Profits, Capital, Credit, Interest and the Business Cycle, translated from the German by Redvers Opie, New Brunswick (U.S.A) and London (U.K.): Transaction Publishers.

Sekaran, U., \& Bougie, R. (2016). Research Methods for Business ,: A skill building approach, $7^{\text {th }}$ Edition. West Sussex: John Wiley \& Sons.
Shapero, A. and Sokol, L. (1982), The social dimensions of entrepreneurship, in Kent, C.A., Sexton, D.L. and Vesper, K.H. (Eds), Encyclopedia of Entrepreneurship, PrenticeHall, Englewood Cliffs.

Steenekamp, A.G., van der Merwe, S.P. \& Athayde,

R. (2011). An investigation into youth entrepreneurship in selected South African secondary schools: An exploratory study. South African Business Review, 15 (3), p. 47.

Turton, N. \& Herrington, M. (2012). GEM South Africa report 2012. Cape Town: University of Cape Town.

Venter D, Van Eeden S \& Viviers S (2003). A Comparative Study of Selected Problems Encountered by Small Businesses in the Nelson Mandela, Cape Town and Egoli Metropoles. Manag. Dyn., 12(3): 13.

Woodruff, C. (2007). Self-employment: Engine of growth or self-help safety net? Chapter 4 in PierellaPaci and Pieter Serneels (eds.) Employment and Shared Growth, The World Bank, Washington DC.

Worstall, T. (2017, Mar 5). Congratulations To Robert Mugabe Zimbabwe's Unemployment Rate Now 95\%. The Forbes Magazine. https://www.forbes.com/sites/ti mworstall/2017/03/05/congratulations-torobert- mugabe-zimbabwes-unemploym ent-rate-n ow-95/?sh=515131d6244c. 